\title{
Avaliação da integridade cromatínica de espermatozóides de galos (Gallus gallus, Linnaeus, 1758) de linhagem pesada em duas idades
}

Jaqueline Melo SOARES ${ }^{1}$ Marcelo Emílio BELETTI ${ }^{1}$

\section{Correspondência para:}

JAQUELINEMELOSOARES

Centro de Ciências Biomédicas.

Universidade Federal de Uberlândia Av: Pará, 1720

38405-320 - Umuarama-MG soaresjaqueline@uol.com.br

mebeletti@centershop.com.br

Recebido para publicação: 06/10/2003 Aprovado para publicação: 15/03/2005

\author{
1 - Centro de Ciências Biomédicas da Universidade Federal de Uberlândia, \\ Umuarama - MG
}

\section{Resumo}

$\mathrm{Na}$ avicultura, a avaliação de fertilidade em machos é de extrema importância, para garantir uma melhor produção de ovos férteis. As técnicas para avaliação de fertilidade em galos são pouco exploradas, sendo que na maioria das vezes, a avaliação é feita por amostragem e levando em consideração, apenas fatores morfofisiológicos, diretamente relacionados com o espermatozóide. Mas é sabido que, em outras espécies, além dos fatores morfofisiológicos, existem problemas intrínsecos ao espermatozóide, como a baixa compactação da cromatina, que pode levar a disturbios de fertilidade, que na maioria das vezes não são diagnosticados. O objetivo desse trabalho foi a adaptação de técnicas de avaliação da cromatina, já descritas em outras espécies, para aves de linhagem pesada (Gallus gallus, Linnaeus, 1758), correlacionando as alterações cromatínicas com as alterações morfológicas e com a fertilidade. Para tanto, sêmen de galo com diferentes níveis de fertilidade, foram utilizados em diferentes métodos para identificação de alterações na cromatina, utilizando os corantes azul de toluidina e alaranjado de acridina. As avaliações demonstraram que esfregaços de sêmen fresco de galo com posterior fixação geram artefatos que levam a alterações na forma da cabeça e na integridade da cromatina, não sendo indicados em métodos de avaliação de fertilidade. Apesar de todos os métodos testados apresentarem falhas metodológicas e um certo grau de subjetividade, o método que gerou melhores resultados foi a mistura de uma gota de sêmen conservado em formol salina e uma gota do alaranjado de acridina sobre lâmina de microscopia, com posterior secagem e observação em microscopia de fluorescência com filtro de excitação azul. Pelo método verificou-se que alterações na compactação da cromatina de espermatozóides de galo geralmente não são acompanhadas por alterações morfológicas e que geralmente as alterações morfológicas de espermatozóides de galo são acompanhadas por alterações na compactação da cromatina e que esse é um importante fator na determinação da fertilidade de galos.

\section{Introdução}

A franca expansão da avicultura e a necessidade de abastecimento dos mercados consumidores de proteína de origem animal, levaram ao avanço no melhoramento genético das aves, elevando seu potencial produtivo. A garantia de volume de aves

\author{
Palavras-chave: \\ Galo. \\ Espermatozóide. \\ Compactação de cromatina. \\ Azul de toluidina. \\ Alaranjado de acridina.
}

comerciais para o abate depende principalmente de matrizes de linhagem pesada (Gallus gallus, Linnaeus, 1758). Partindo dessa realidade, as matrizes são exploradas ao máximo em seus recursos reprodutivos, sendo a fertilidade dos machos, de fundamental importância na produção de ovos férteis. 
Um lote de aves reprodutoras geralmente entra em pico de produção de ovos na $30^{\mathrm{a}}$ à $35^{\mathrm{a}}$ semana de vida e são descartadas por volta da $58^{a}$ semana, podendo essa idade de abate ser prorrogada, de acordo com a necessidade do mercado. Com o passar do tempo, a produção e a fertilidade do lote diminuem consideravelmente ${ }^{1}$, havendo inclusive necessidade de reposição de parte dos machos, recurso utilizado para melhorar a fertilização. Assim, a avaliação da fertilidade de cada reprodutor é de extrema relevância, sendo necessários métodos precisos e de baixo custo.

As técnicas para diagnóstico de fertilidade em galos são pouco exploradas. Muitas vezes, os parâmetros fisiológicos como peso corporal, peso testicular, dieta alimentar e idade da ave são correlacionados a virilidade. Fatores morfofisiológicos facilmente evidenciados na microscopia de luz em preparados de sêmen fresco e diretamente relacionados com o espermatozóide, tais como motilidade, densidade, vitalidade e morfologia espermática, também são usados para a avaliação da fertilidade do macho. Este tipo de metodologia vem sendo utilizado na rotina de avaliação da fertilidade de machos em mamíferos, contudo estudos têm demonstrado que esta avaliação não é suficiente para identificar algumas alterações espermáticas que podem levar à subfertilidade, tais como alterações na compactação da cromatina dos espermatozóides. Como esta patologia não é evidenciada num exame de rotina, são necessários métodos específicos de avaliação dessa anomalia.

O objetivo desse trabalho procura adaptar técnicas de avaliação da compactação da cromatina, já descritas em outras espécies, para aves de linhagem pesada (Gallus gallus, Linnaeus, 1758), correlacionando as alterações cromatínicas com as alterações morfológicas e com a fertilidade.

\section{Materiais e Métodos}

Foram obtidos 20 amostras de sêmen de galo (Gallus gallus, Linnaeus, 1758) de duas diferentes idades, coletadas através de massagem cloacal, de acordo coma técnica descrita por Wilson ${ }^{2}$. Dez amostras foram de aves pertencentes a um lote com 35 semanas de idade, peso médio de 4,9 Kg e taxa de fertilidade de $99.43 \%$ de ovos férteis (Grupo I). As demais amostras foram coletadas de aves pertencentes a um lote com 60 semanas de idade, peso médio de $5,3 \mathrm{Kg}$ e taxa de fertilidade de $96.41 \%$ de ovos férteis (Grupo II).

De cada amostra de sêmen foram produzidos 20 esfregaços com posterior fixação em mistura álcool-ácido acético 3:1 durante 1 minuto e lavadas em álcool 70\% por 3 minutos. O restante de cada amostra foi conservado em formol-salina ${ }^{3}$.

\section{Métodos Utilizando AT:}

\section{Método usual para sêmen de mamífero:}

1.1-. Metade dos esfregaços foi avaliada segundo método de Beletti e Mello ${ }^{4}$, ou seja, após hidrólise ácida com $\mathrm{HCl} 4 \mathrm{~N}$ por 15 minutos, coloca-se uma gota de solução de AT a $0,025 \%$ a pH 4 em tampão MacIlvaine, cobre-se com lamínula observase através de microscopia óptica.

Métodos alternativos também foram testados como estão descritos a seguir:

1.2- Mistura de uma gota de sêmen conservado em formol salina e uma gota do corante sobre lâmina de microscopia. Após homogeneização a mistura foi coberta com lamínula, sendo feita a observação após 5 minutos em microscopia óptica.

1.3- Mistura de uma gota de sêmen conservado em formol salina e uma gota do corante sobre lâmina de microscopia com posterior secagem e observação em microscopia de luz comum.

1.4- Mistura de uma gota de sêmen conservado em formol salina e uma gota do corante sobre lâmina de microscopia, com posterior secagem, desidratação em álcool, diafanização em xilol e montagem da lâmina com Entellan ${ }^{\circledR}$ e lamínula, para observação em microscopia de luz comum. 
1.5- Mistura de uma gota de sêmen conservado em formol salina e uma gota do corante sobre lâmina de microscopia, com posterior secagem, lavagem em água destilada, secagem, diafanização e montagem da lâmina, com Entellan ${ }^{\circledR}$ e lamínula, para observação em microscopia de luz comum.

\section{Métodos Utilizando AO:}

Método usual para sêmen de mamífero:

2.1 - $\mathrm{Na}$ coloração com AO a metodologia modificada de Tejada et $\mathrm{al}^{5}$ é a mais indicada para esfregações de mamífero. Foi utilizada uma solução "stock" constituída de $1 \mathrm{~g}$ de alaranjado de acridina diluído em $1000 \mathrm{ml}$ de água destilada. A solução de coloração foi preparada tomando-se $10 \mathrm{ml}$ da solução "stock" e adicionando $40 \mathrm{ml} \mathrm{de}$ ácido cítrico a $0,1 \mathrm{M}$ e $2,5 \mathrm{ml}$ de $\mathrm{Na}_{2} \mathrm{HPO}_{4} \cdot 7 \mathrm{H}_{2} \mathrm{O}$ a $0,3 \mathrm{M}$. O pH final da solução preparada foi de $2,5 \mathrm{com}$ concentração de corante de $0,019 \%$. O método consistia na coloração do esfregaço por 5 minutos, com posterior secagem e observação em microscopia de fluorescência com filtro de excitação azul.

Métodos alternativos também foram testados como estão descritos a seguir:

2.2- Mistura de uma gota de sêmen conservado em formol salina e uma gota de AO sobre lâmina de microscopia com posterior secagem e observação em microscopia de fluorescência com filtro de excitação azul.

2.3- Desnaturação da cromatina, através de tratamento térmico a $60^{\circ} \mathrm{C} \mathrm{em}$ solução fisiológica por cinco minutos. Em seguida foi colocada uma gota de corante, com posterior homogeneização, secagem e observação em microscopia de fluorescência com filtro de excitação azul.

2.4- Mistura de uma gota de sêmen conservado em formol salina e uma gota do corante sobre lâmina de microscopia. Após homogeneização a mistura foi coberta com lamínula, sendo feita a observação após 5 minutos em microscopia de fluorescência com filtro de excitação azul.
As lâminas foram observadas em fotomicroscópio Polyvar-Reichert Jung, em modo de operação transiluminação e fluorescência com filtro azul, no Laboratório de Histologia do Instituto de Ciências Biomédicas da Universidade Federal de Uberlândia.

Foram calculados os Coeficientes de Variação das 10 avaliações realizadas para cada animal e posteriormente o coeficiente de variação médio, incluindo grupo I e II. Foi realizado teste "t" não pareado comparando os grupos I e II para diferenças quanto à quantidade de espermatozóides com anomalias na cromatina e espermatozóides com anomalias morfológicas. Foram calculados os coeficientes de correlação entre a quantidade de espermatozóides com anomalias morfológicas e os com anomalias cromatínicas de duas diferentes maneiras: levando em consideração todos os espermatozóides avaliados e considerando somente os espermatozóides com defeitos morfológicos. Também foi realizado teste " $\mathrm{t}$ " pareado comparando a quantidade de espermatozóides morfológicamente anômalos com alterações de cromatina e espermatozóides morfológicamente anômalos e sem defeito de cromatina. Em todos os testes estatísticos foi utilizado nível de significância $\mathrm{a}=0,05$.

\section{Resultados}

\section{Esfregaços:}

Os esfregaços, independente da técnica de coloração utilizada, apresentaram todos os espermatozóides como tendo alterações na cromatina, ou seja, todos os espermatozóides ficaram violetas quando corados com AT (Método 1.1) e vermelhos quando corados com AO (Método 2.1). Outras observações indicaram que as cabeças dos espermatozóides apresentavam-se na forma de um bastão retilíneo e com pequenas fraturas transversais. (Figura 1A e 1B).

Sêmen preservado em formol-salina:

Através dos preparados obtidos do 
sêmen preservado em formol-salina foi possível observar que os espermatozóides possuem na realidade a cabeça levemente helicoidal.

\section{Métodos com AT:}

No método 1.2 os espermatozóides apresentaram-se corados em azul intenso. Outras observações indicaram a existência

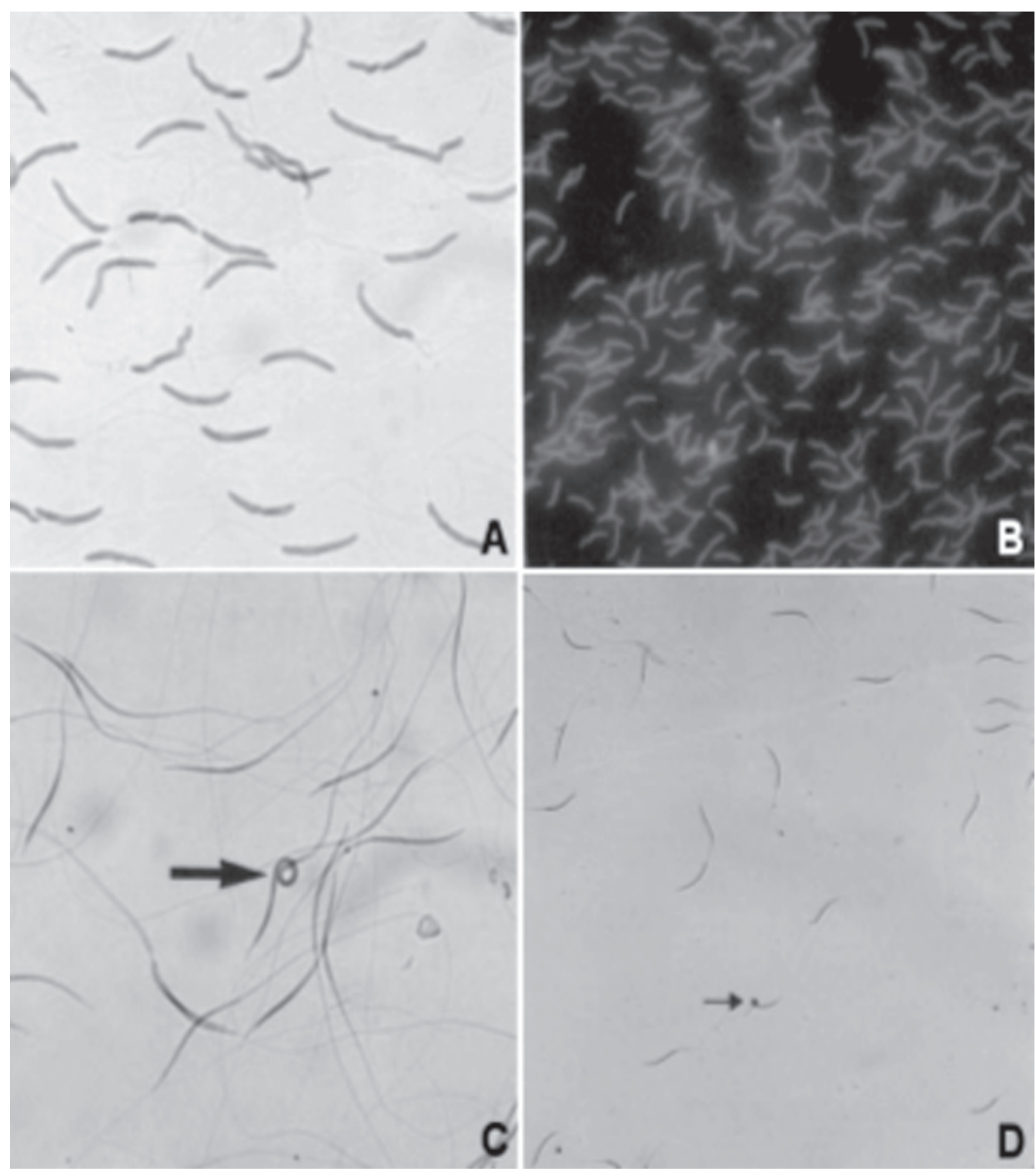

Figura 1 - A: Esfregaço de espermatozóide corado com AT, com todas as células apresentando coloração violeta, devido às fraturas do núcleo e penetração abundante de corante. (Aumento de 1.200X)

B: Esfregaço de espermatozóide corado com AO, com todas as células apresentando coloração vermelha, devido às fraturas do núcleo e penetração abundante de corante. (Aumento de 500X) C: Método 1.2 (Mistura de uma gota de sêmen conservado em formol salina e uma gota de AT sobre lâmina de microscopia. Após homogeneização a mistura foi coberta com lamínula, sendo feita a observação após 5 minutos em microscopia de luz comum), apresentando os espermatozóides corados em azul intenso. Observa-se um espermatozóide com cabeça enrolada e levemente mais corada (seta). (Aumento de 1.200X) D: Método 1.3 (Mistura de uma gota de sêmen conservado em formol salina e uma gota de AT sobre lâmina de microscopia com posterior secagem e observação em microscopia de luz comum), apresentando os espermatozóides corados em azul intenso. Percebe-se espermatozóide apresentando dilatação na base da cabeça (seta). (Aumento de 500X) 


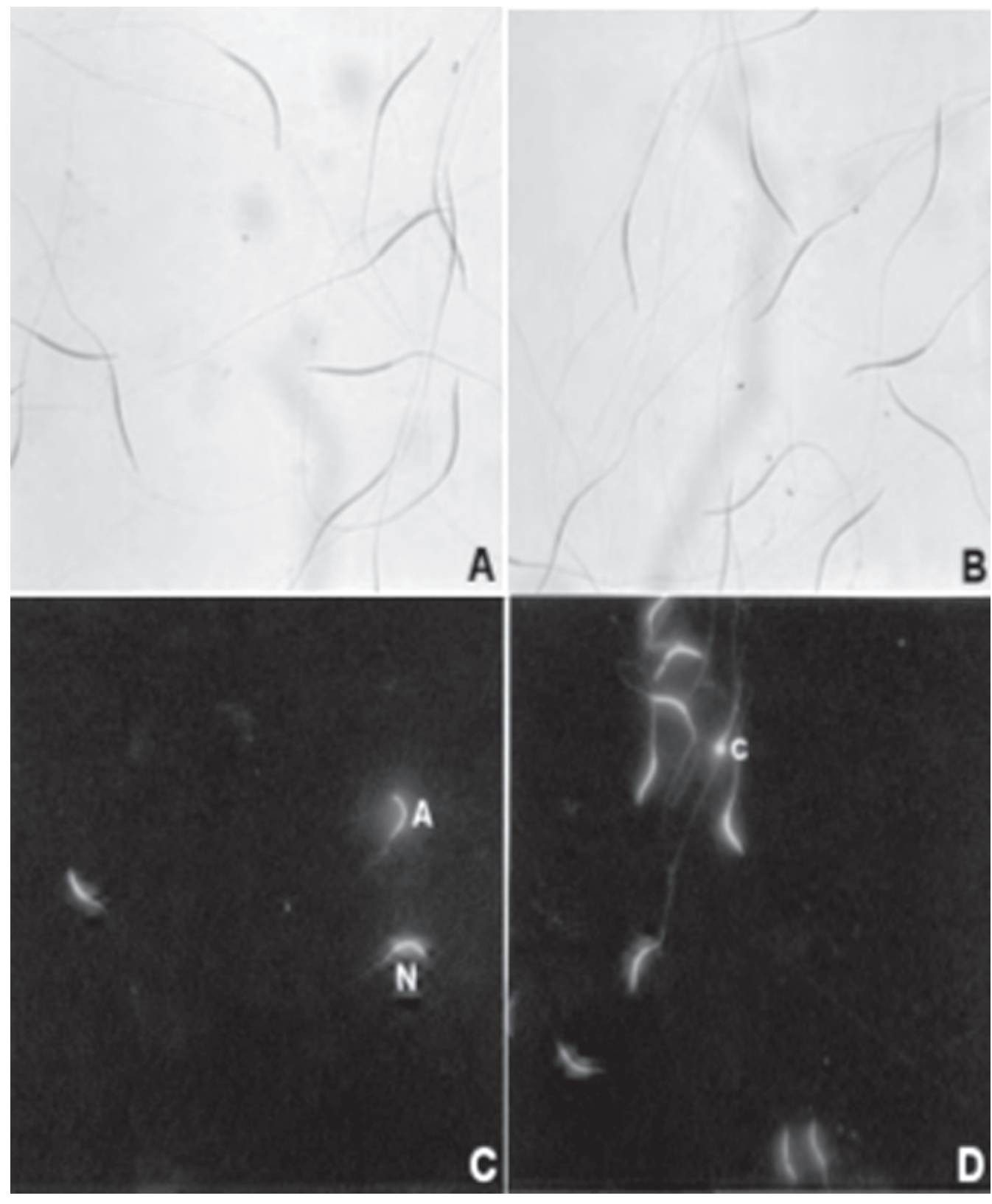

Figura 2-A: Método 1.4 (Mistura de uma gota de sêmen conservado em formol salina e uma gota de AT sobre lâmina de microscopia, com posterior secagem, desidratação em álcool, diafanização em xilol e montagem da lâmina com Entellan e e lamínula, para observação em microscopia de luz comum), com espermatozóides corados em azul mais claro. (Aumento de 1.200X) B: Método 1.5 (Mistura de uma gota de sêmen conservado em formol salina e uma gota de AT sobre lâmina de microscopia, com posterior secagem, lavagem em água destilada, secagem, diafanização e montagem da lâmina, com Entellan e e lamínula, para observação em microscopia de luz comum), com espermatozóides corados em azul mais claro. (Aumento de 1.200X) C: Método 2.2 (Mistura de uma gota de sêmen conservado em formol salina e uma gota de AO sobre lâmina de microscopia com posterior secagem e observação em microscopia de fluorescência com filtro de excitação azul) mostrando parte dos espermatozóides corados em verde (cromatina normal-N) e parte em vermelho (cromatina anormal-A). (Aumento de 500X) D: Método 2.2 (Mistura de uma gota de sêmen conservado em formol salina e uma gota de $\mathrm{AO}$ sobre lâmina de microscopia com posterior secagem e observação em microscopia de fluorescência com filtro de excitação azul), parte da lâmina, onde a diferenciação estava dificultada, apresentando espermatozóide com cabeça arredondada (C), pequena, fortemente corada em vermelho e brilhante. (Aumento de 500X) 


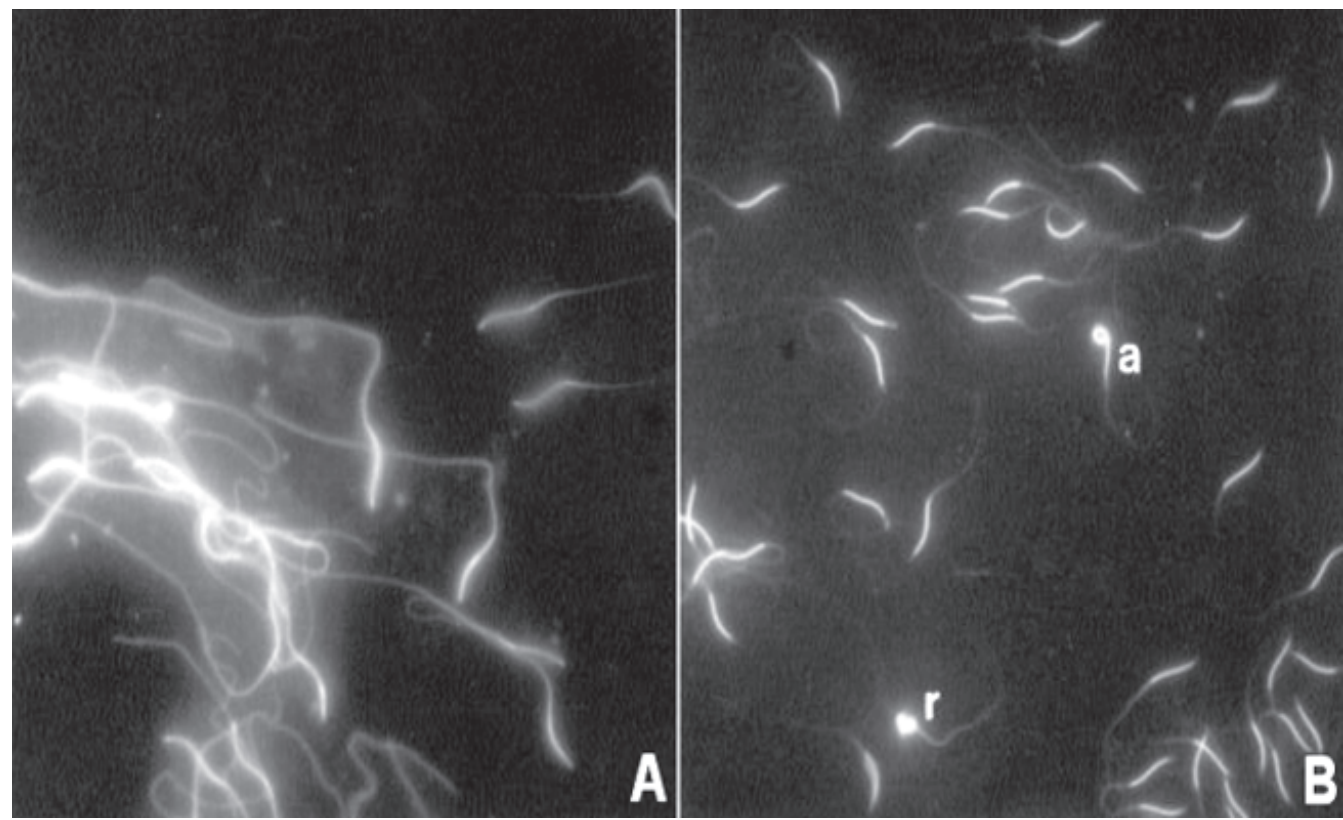

Figura 3 - A: Método 2.3 (Desnaturação da cromatina, através de tratamento térmico a $60^{\circ} \mathrm{C}$ em solução fisiológica por cinco minutos. Em seguida foi colocada uma gota de $\mathrm{AO}$, com posterior homogeneização, secagem e observação em microscopia de fluorescência com filtro de excitação azul), com todos os espermatozóides corados em vermelho. (Aumento de 500X) B: Método 2.4 (Mistura de uma gota de sêmen conservado em formol salina e uma gota de AO sobre lâmina de microscopia. Após homogeneização a mistura foi coberta com lamínula, sendo feita observação após 5 minutos em microscopia de fluorescência com filtro de excitação azul), com

"background" levemente corado. Pode-se identificar dois defeitos morfológicos nessa figura: cabeça em anzol (a) e cabeça arredondada (r). (Aumento de 500X)

de cabeças coradas com diferentes intensidades, porém, devido às diferenças serem muito tênues, foi praticamente impossível quantificar os espermatozóides com cromatina normal dos com cromatina anormal (Figura 1C). O método 1.3 apresentou resultado foi bastante semelhante (figura 1D). Já nos métodos 1.4 e 1.5, os espermatozóides apresentaram-se corados em azul mais claro, mas ainda assim foi difícil a identificação de espermatozóides com cromatina anômala, não possibilitando a contagem diferencial dos espermatozóides (Figura 2A e 2B).

\section{Métodos com AO:}

O método 2.2 mostrou parte dos espermatozóides corados em verde e parte em vermelho, porém as lâminas apresentaram partes onde a diferenciação foi mais evidente (Figura 2C). Estes preparados foram utilizados para a contagem de 500 espermatozóides, diferenciando-se esperma- tozóides com ou sem alterações de cromatina e com ou sem alterações morfológicas, sendo que os resultados obtidos estão demonstrados nas tabelas 1 e 2 . Durante as observações foram verificadas colorações variando de verde ao vermelho intenso, sendo que geralmente os espermatozóides com anomalias morfológicas eram corados em vermelho. Os defeitos morfológicos observados foram cabeça em anzol, enrolada (Figura 1C), dobrada, com dilatação na base (Figura 1D) e arredondada, sendo que na maioria das vezes este último tipo apresentava cabeça pequena, fortemente corada em vermelho e brilhante (Figura 2D). No método 2.3 todos os espermatozóides apresentaram-se vermelhos (Figura 3A). Já no método 2.4 o fundo ficou levemente fluorescente e os espermatozóides apresentaram intensa variação na cor das cabeças dependendo da região da lâmina observada. Isto impossibilitou a contagem diferencial dos espermatozóides (Figura 3B). 
Tabela 1- Média dos espermatozóides com anomalia cromatínica e coeficiente de variação (CV) das 10 avaliações feitas em cada animal. Uberlândia, Maio de 2004

\begin{tabular}{|c|c|c|}
\hline Animais & $\begin{array}{c}\text { Média de espermatozóide com anomalias de } \\
\text { cromatina }\end{array}$ & $C V$ \\
\hline \multicolumn{3}{|l|}{ Grupo I } \\
\hline 1 & 132 & 13.9 \\
\hline 2 & 148 & 19.5 \\
\hline 3 & 145 & 18.1 \\
\hline 4 & 165 & 10.4 \\
\hline 5 & 158 & 12.7 \\
\hline 6 & 148 & 16.8 \\
\hline 7 & 159 & 13.9 \\
\hline 8 & 163 & 16 \\
\hline 9 & 180 & 12.9 \\
\hline 10 & 172 & 9.8 \\
\hline \multicolumn{3}{|l|}{ Grupo II } \\
\hline 1 & 212 & 8.8 \\
\hline 2 & 214 & 12.3 \\
\hline 3 & 189 & 4.8 \\
\hline 4 & 207 & 8.3 \\
\hline 5 & 211 & 12.6 \\
\hline 6 & 235 & 11.6 \\
\hline 7 & 191 & 11.8 \\
\hline 8 & 253 & 10.5 \\
\hline 9 & 255 & 7.2 \\
\hline 10 & 227 & 8.4 \\
\hline Médias Totais. & 188 & 12.02 \\
\hline
\end{tabular}

Tabela 2- Médias dos espermatozóides com anomalia cromatínica e com anomalias morfológicas. Uberlândia, Maio de 2004

\begin{tabular}{ccc}
\hline & Galos Novos & Galos Velhos \\
\hline Anomalias de cromatínicas & $156.8^{\mathrm{a}}$ & $219.4^{\mathrm{b}}$ \\
Anomalias morfológicas & $6.6^{\mathrm{a}}$ & $4.7^{\mathrm{b}}$ \\
\hline
\end{tabular}

Letras diferentes na mesma linha indicam valores estatisticamente diferentes (á=0,05).

O coeficiente de correlação entre os espermatozóides com anomalias na cromatina e os espermatozóides com anomalias morfológicas foi - 0,54 , quando considerado o total de espermatozóides avaliados. Já quando foram considerados somente os espermatozóides anômalos morfologicamente, o coeficiente de correlação foi 0,97 . $\mathrm{O}$ teste " $\mathrm{t}$ " pareado demonstrou que existe diferença na quantidade de espermatozóides morfologicamente anômalos com alterações de cromatina e espermatozóides morfologicamente anômalos e sem defeito de cromatina (média de 5,52 e 1,16 respectivamente).

\section{Discussão}

Esfregaços:

Os métodos de coloração utilizando 
esfregaços (Métodos 1.1 e 2.1) apresentaram todos os espermatozóides com alterações na cromatina. Isto evidentemente não é um resultado aceitável, pois as aves utilizadas neste experimento eram férteis. Portanto, este resultado é devido a algum tipo de artefato provocado pelo método utilizado. A outra parte do sêmen que foi preservado em formol-salina para posteriormente ser preparado, mostrou que a cabeça dos espermatozóides de galo possui uma forma levemente helicoidal ${ }^{6}$, diferente da forma em bastão observada nos esfregaços. Apesar destas observações diferirem de Gilbert ${ }^{7}$, que afirma que a cabeça do espermatozóide de galo é curva, a estrutura levemente helicoidal explicaria as observações dos esfregaços. Quando depositada em superfície plana, a cabeça helicoidal acaba tomando a forma em bastão, exibindo pequenas fraturas transversais provocada pela alteração da forma. Isto provavelmente alterou o acesso das moléculas de corante, fazendo com que todos os espermatozóides fossem corados como possuindo alterações na cromatina. $\mathrm{Na}$ realidade estas alterações existem, porém foram provocadas pela metodologia utilizada. Assim, foram testados métodos alternativos, utilizando o material preservado em formal-salina (Métodos: 1.2, 1.3, 1.4, 1.5, $2.1,2.2,2.3)$. Esses preparados foram montados com uma gota de sêmen homogeneizada a uma gota de corante, havendo algumas variantes, sendo essa mistura distribuída levemente sobre a lâmina, sem danos para as células.

\section{Métodos com AT}

Os preparados realizados com AT entre lâmina e lamínula (Método 1.2) ou com posterior secagem da lâmina e observação sem o uso da lamínula (Método 1.3), mostraram todos os espermatozóides com coloração azul intensa. Isto demonstra que os espermatozóides de galo possuem cromatina mais frouxa que o da maioria dos mamíferos, pois para se obter visualização semelhante nestes animais é necessário tratamento ácido ou térmico antes da coloração. Este tratamento prévio disponibiliza grupos fosfatos que posteriormente se ligam ao corante, aumentando a intensidade de coloração e mesmo provocando metacromasia $3,8,9,10,11,12$. Em espermatozóides de galo o tratamento prévio não foi necessário porque grande número de fosfatos estão livres para se ligarem às moléculas de corante, mesmo na cromatina normal. Contudo, com uma observação cuidadosa foi possível perceber a existência de espermatozóides que se coravam um pouco mais intensamente. Esta diferença era muito tênue, não permitindo a contagem diferencial de espermatozóides com cromatina normal (mais claros) e com cromatina anômala (mais escuros). Devido a tênue diferença entre espermatozóides anômalos e normais, foram feitas tentativas de montagem dos preparados, através de desidratação e diafanização (Método 1.4). Porém não houve separação adequada dos espermatozóides normais dos anômalos, corando todos em azul claro, não possibilitando assim a contagem diferencial. Outra tentativa de montagem foi feita sem desidratação, apenas com lavagem da lâmina em água destilada e diafanização (Método 1.5). Nesse caso, o resultado foi muito semelhante ao anterior. Portanto, os métodos utilizando AT não se mostraram satisfatórios na avaliação da compactação de cromatina de espermatozóides de frango.

\section{Métodos com AO}

Dentre os métodos alternativos realizados com $\mathrm{AO}$, a mistura de uma gota de sêmen conservado em formol salina e uma gota do corante sobre lâmina de microscopia com posterior secagem e observação em microscopia de fluorescência (Método 2.2) foi o que apresentou melhor resultado, possibilitando a contagem diferencial dos espermatozóides com alteração de cromatina. Contudo, ainda permaneceu longe do ideal, pois numa mesma lâmina existiam regiões onde a diferenciação era evidente e outras onde era praticamente impossível. A contagem 
diferencial foi realizada nas regiões onde a diferenciação era mais evidente.

Objetivando, potencializar a diferenciação entre cromatina anômala e normal, foi realizada a desnaturação térmica antes da coloração com AO (Método 2.3). Nesse método todos os espermatozóides apresentaram-se corados em vermelho. A desnaturação da cromatina possibilitou a ligação de grande quantidade de moléculas de corante aos fosfatos do DNA, permitindo a ressonância dos elétrons entre elas, tornando a coloração de todas os espermatozóides vermelha, característica de DNA desnaturado. Isto também demonstra que a cromatina de espermatozóides de galo é mais frouxa que a cromatina de espermatozóide da maioria dos mamíferos, pois quando este tratamento é feito com espermatozóides destes animais, somente aqueles com alteração na cromatina coram-se em vermelho.

Na utilização da lamínula cobrindo a mistura de sêmen e AO (Método 2.4) o "background" ficou levemente corado e os espermatozóides apresentaram intensa variação na cor das cabeças dependendo da região da lâmina observada. Isto impos-sibilitou a contagem diferencial dos espermatozóides.

Apesar dos métodos com AO também apresentarem falhas, eles foram melhores que os métodos com AT na identificação de alterações na cromatina de espermatozóides de galo. O coeficiente de variação médio em dez avaliações para cada amostra foi de 12,02, demonstrando que apesar das lâminas não corarem homogeneamente em toda sua extensão, o método possui uma razoável repetibilidade, viabilizando seu uso.

\footnotetext{
Avaliaçãogeral

Segundo Hammadeh et al..$^{13}$, submetendo sêmen humano a exames com Azul de Anilina, não obtiveram correlação entre condensação cromatínica do espermatozóide e defeitos de morfologia. Assim, concluíram que compactação da cromatina é parâmetro adicional para a avaliação da fertilidade no macho, sendo este independente de outros
}

parâmetros convencionais. No presente trabalho também fica evidente a necessidade da análise na compactação de cromatina, em sêmen de galo, obtendo resultados independentes de outros parâmetros convencionais de avaliação de sêmen. Como descrito em Material e Métodos, a porcentagem de ovos férteis $99.43 \%$ do grupo I é maior do que $96.41 \%$ do grupo II. Por isso era espera do que o número de espermatozóides anômalos no grupo II fosse maior. Contudo, como demonstrado na tabela 2 , o número de espermatozóides morfologicamente anômalos foi maior no grupo I. Já o número de espermatozóides com alterações na cromatina foi muito maior no grupo II. Isto reafirma ainda mais a necessidade de se utilizar métodos de identificação de alterações cromatínicas quando se avalia a fertilidade de galos.

Quando considerado o total de espermatozóides avaliados, o coeficiente de correlação entre os espermatozóides com anomalias na cromatina e os espermatozóides com anomalias morfológicas foi -0,54. Isto indica que nas amostras avaliadas existe uma correlação negativa entre estas duas patologias, ou seja, geralmente quando o número de espermatozóides com anomalias morfológicas aumenta, o número de espermatozóides com anomalias de cromatina diminui. Isto poderia indicar que os espermatozóides com anomalias morfo-lógicas geralmente possuem cromatina normal. Porém, quando são levados em consideração somente os espermatozóides com anomalias morfológicas, o coeficiente de correlação entre essas anomalias é de 0,97 e o numero de espermatozóides com anomalias de cromatina é maior dos que os com cromatina normal, deixando claro que geralmente os espermatozóides anômalos morfologicamente possuem alterações cromatínicas.

\section{Conclusões}

A coloração com AO apesar de possuir falhas que levam a um certo grau de subjetividade, mostrou-se útil na avaliação da compactação da cromatina. 
A coloração com AT foi pouco eficiente na avaliação da compactação da cromatina.

Esfregaços de sêmen fresco de galo com posterior fixação geram artefatos que levam a alterações na forma da cabeça e na integridade da cromatina, não sendo indicados em métodos de avaliação de fertilidade.

Os espermatozóides anômalos morfologicamente, geralmente possuem alterações cromatínicas, mas nem sempre os que possuem alterações cromatínicas apresentam alterações morfológicas.

\title{
Evaluation of chromatin integrity of fowl spermatozoa (Gallus gallus, Linnaeus, 1758) from meat chicken in two ages
}

\begin{abstract}
In poultry breeding, male fertility has extreme importance to assure a better production of fertile eggs. Evaluation techniques for fertility of fowls are not well explored and in most cases, the evaluation is done through sampling considering only morphophysiological factors directly related with the spermatozoon. It's known that in other species, besides morphophysiological factors, there are intrinsic problems to the spermatozoon such as less chromatin condensation that can lead to fertility problems that in most cases are not diagnosised. The purpose of this work was the adaptation of techniques of chromatin evaluation for chicken (Gallus Gallus, Linnaeus, 1758) which have already been described in other species, correlating the chromatin alterations with the morphological alterations and the fertility. Fowl semen samples with different levels of fertility were used for test different methods to identify chromatin alterations using toluidine blue and acridine orange die. Evaluations have shown that smears of fresh semen with posterior fixation generate artfacts that change the head shape and the chromatin integrity not being indicated in methods of fertility evaluation. Although all the tested methods have presented methodology imperfections and some certain degree of subjectivity, the method that has generated best results was the mixture of one semen drop conserved in buffered phormol and a drop of acridine orange on microscopy slide with posterior staining and observation in fluorescence microscopy with blue excitation filter. Through this method it was verified that alterations in the chromatin condensation of fowl spermatozoa are generally not followed by morphological alterations and that generally the morphologic alterations of fowl spermatozoa are generally followed by alterations in chromatin condensation. This is an important factor in the determination of the fowl fertility.
\end{abstract}

\section{Referências}

1 LEESON, S.; SUMMERS, J. D. Comercial poultry nutrition. 2. ed. Guelph, Ontario: University Books, 1997. 342 p.

2 WILSON, J. L. Métodos para valorar la capacidad reproductiva en gallos reproductores. Avicultura Profesional, v. 6, n. 3, p. 76-81, 1988.

3 WEITZE, K. F. Untersuchung zur tiefgefrierkon-
Key-words:

Fowl.

Spermatozoon. Chromatin condensation. Toluidine blue. Acridine orange. servierung von kaninchensperma. 1977. 165 f. Tese (Livre docência)-Tierärztliche Hochsehule, Hannover, 1977.

4 BELETTI, M. E.; MELLO, M. L. S. Testicular and semen alteration after three days of experimental cryptorchidism in rabbit. Brazilian Journal of Morphological Science, v. 14, p. 88-88, 1997.

5 TEJADA, R. l.et al. A test the practical evaluation of male fertility by acridine orange (LA) fluorescence. Fertility and Sterility, v. 42, p. 87-91, 1984. 
6 GOES, R. M.; DOLDER, H. Cytological steps during spermiogenesis in the house sparrow (Passer domesticus, Linnaeus). Tissue \& Cell, v. 34, n. 4, p. 273-282, 2002.

7 GILBERT, A. B. Ciclos reprodutivos: aves domésticas. In: HAFEZ, E.S.Z. Reprodução animal. São Paulo: Manole, 1982. p. 488-515.

8 MELLO, M. L. S. DNP variants in morphologically normal spermatozoa. In CONGRESSO LATINOAMERICANO DE GENÉTICA,3;1977, Montevidéu. Resumos...1977,p. 250.

9 EVENSON, D. P.; DARZYNKIEWICZ, Z; MELAMED, M. R. Relation of mammalian sperm chromatin heterogeneity to fertily. Science, v. 210, p. 1131-1133, 1980.

10 BELETTI, M. E. MELLO, M. L. S. Methodological variants contributing to detection of abnormal DNAprotein complexes in bull spermatozoa. Brazilian Journal of Genetics, v. 19, n. 1, p. 73-90, 1996.

11 EVENSON, D.P.; LARSON, K.L,; JOST, LK. Sperm chromatin structure assay is useful for fertility assessment. Methods Cell Science, v. 22, n.2-3, p.16989, 2002.

12 ROCHA, H. L. O. G.; BELETTI, M. E.; MARCOLINI, T.T.; AMORIM, D. A. Z. The use of acridine orange and toluidine blue in the evaluation of male fertility. Bioscience Journal, v. 18, n. 1, p. 65-77, 2002

13 HAMMADEH, ME. et al. Predictive value of sperm chromatin condensation (aniline blue staining) in the assessment of male fertility. Archives of Andrology $v$. 46, n. 2, p. 99-104, Mar-Apr, 2001. 